\title{
Competition for nitrate and glucose between Pseudomonas fluorescens and Bacillus licheniformis under continuous or fluctuating anoxic conditions
}

\author{
Johanna W. Nijburg ${ }^{\mathrm{a}, *}$, Saskia Gerards ${ }^{\mathrm{a}}$, Hendrikus J. Laanbroek b \\ ${ }^{a}$ Netherlands Institute of Ecology, Centre for Terrestrial Ecology, Department of Plant-Microorganism Interactions, P.O. Box 40, \\ 6666 ZG Heteren, The Netherlands \\ b Netherlands Institute of Ecology, Centre for Limnology, Department of Microbial Ecology, Rijksstraatweg 6, 3631 AC Nieuwersluis, \\ The Netherlands
}

Received 10 September 1997; revised 24 February 1998; accepted 4 June 1998

\begin{abstract}
The dissimilatory nitrate-reducing bacterial community in the rhizosphere of aerenchymatous plant species such as Glyceria maxima, consists of oxidative, denitrifying and fermentative nitrate-ammonifying bacteria. To study the respective ecological niches of both types of nitrate-reducing bacteria, competition for nitrate or glucose between the representative denitrifier Pseudomonas fluorescens and the representative fermentative nitrate-ammonifying Bacillus licheniformis under continuous or fluctuating anoxic conditions were performed in continuous culture. Competition started by mixing the separate, steady-state mono-cultures of the two species at different ratios. All the experiments were performed at a dilution rate of $0.05 \mathrm{~h}^{-1}$. The competition was followed by measuring concentrations of nitrogen, glucose and fatty acids and by determining the cell numbers of $P$. fluorescens and $B$. licheniformis. Under continuous anoxic nitrate-limited conditions and under certain fluctuating anoxic conditions ( $8 \mathrm{~h} \mathrm{10 \%} \mathrm{and} 16 \mathrm{~h} 0 \%$ air saturation), B. licheniformis was able to maintain itself in the chemostat at a low percentage of $4-7 \%$. Under continuous anoxic glucose-limited conditions and under specific fluctuating anoxic (16 h $10 \%$ and $8 \mathrm{~h} 0 \%$ air saturation) conditions, B. licheniformis washed out. The outcome of the competition was explained by a higher affinity of $P$. fluorescens for nitrate and glucose compared to B. licheniformis. B. licheniformis was able to maintain itself in the chemostat under continuous anoxic nitrate-limited conditions and under certain fluctuating anoxic conditions $(8 \mathrm{~h} 10 \%$ and $16 \mathrm{~h} \mathrm{0} \%$ air saturation) due to the fermentation of the remaining glucose. (c) 1998 Federation of European Microbiological Societies. Published by Elsevier Science B.V. All rights reserved.
\end{abstract}

Keywords: Competition; Nitrate reduction; Chemostat; Pseudomonas fluorescens; Bacillus licheniformis

\section{Introduction}

Denitrification and dissimilatory nitrate reduction

\footnotetext{
* Corresponding author. Tel.: +31 (26) 4791306 ; Fax: +31 (26) 47232 27; E-mail: Nijburg@cto.nioo.knaw.nl
}

to ammonium, for short nitrate ammonification, are the two known dissimilatory nitrate-reducing pathways. Denitrification by oxidative bacteria such as Pseudomonas spp., leads to the formation of gaseous products such as nitric oxide (NO), nitrous oxide $\left(\mathrm{N}_{2} \mathrm{O}\right)$ and molecular nitrogen $\left(\mathrm{N}_{2}\right)$ [1]. Fermentative 
strains, such as Bacillus spp., reduce nitrate $\left(\mathrm{NO}_{3}^{-}\right)$to nitrite $\left(\mathrm{NO}_{2}^{-}\right)$and subsequently to ammonium $\left(\mathrm{NH}_{4}^{+}\right)$ [2]. The distribution and activity of denitrifying and nitrate-ammonifying bacteria is mainly determined by the relative availability of carbon, nitrate and oxygen [2-4]. In the rhizosphere of flooded aerenchymatous plants oxygen is released, therefore affecting the electron donor/electron acceptor ratio $[5,6]$. Nitrification can occur in the rhizosphere of aerenchymatous plants due to this oxygen release [7]. For example, in the rhizosphere of Glyceria maxima (Hartman) Holm. (reed sweet grass) nitrification is stimulated [8,9]. Diffusion of this nitrate to anoxic sites enables nitrate reduction to take place. The nitrate concentration will be lowered not only by nitrate reduction but also by nitrate uptake by the plant $[10,11]$. Organic substrates are also released into the rhizosphere of aerenchymatous plants $[12,13]$, thereby increasing the concentration of available organic substrates.

It has been shown that in the rhizosphere of $G$. maxima fermentative bacteria potentially dissimilating $\mathrm{NO}_{3}^{-}$to $\mathrm{NH}_{4}^{+}$were dominant when $\mathrm{NO}_{3}^{-}$was limiting or absent $[11,14]$. Under all other conditions, potentially denitrifying bacteria become dominant. G. maxima only exerts a major influence on the nitrate-reducing bacterial community under conditions of $\mathrm{NO}_{3}^{-}$limitation, probably due to the excretion of organic compounds. Based on these results, we postulated that when $\mathrm{NO}_{3}^{-}$is not present in an anoxic sediment, bacteria capable of dissimilating $\mathrm{NO}_{3}^{-}$ to $\mathrm{NH}_{4}^{+}$become dominant due to their fermentative metabolism, since they are able to generate energy in the absence of external electron acceptors. However, when oxygen is released into the rhizosphere nitrification can take place. At that moment, the $\mathrm{NO}_{3}^{-}$ uptake rate by the fermentative community, able to reduce nitrate, is greater than that of the relatively few denitrifying cells, and hence most nitrate will be reduced to ammonium. If the maximum growth rate $\left(\mu_{\max }\right)$ of the denitrifying bacteria, however, is greater than that of the fermentative nitrate-reducing bacteria, the denitrifying bacteria will outgrow the others and the proportion of nitrate reduced to dinitrogen will increase, especially when $\mathrm{NO}_{3}^{-}$is available over a longer time period.

In order to understand and predict the behaviour of a potentially nitrate-reducing community in rela- tion to $\mathrm{NO}_{3}^{-}$availability, competition experiments were performed in a chemostat with the denitrifying species Pseudomonas fluorescens and the fermentative nitrate-reducing species Bacillus licheniformis, both isolated from the rhizosphere of G. maxima [11].

The aim of these experiments was to determine which factor(s) (carbon, nitrate or oxygen) controls the competition between $P$. fluorescens and B. licheniformis under continuous or fluctuating anoxic conditions.

\section{Materials and methods}

\subsection{Bacterial strains}

The experiments were performed with a denitrifying strain of Pseudomonas fluorescens (Biovar III or IV) and a nitrate-ammonifying strain of Bacillus $l i$ cheniformis, able to dissimilate $\mathrm{NO}_{3}^{-}$to $\mathrm{NH}_{4}^{+}$, both isolated as dominant representatives of the nitratereducing community from the rhizosphere of $G$. maxima [11]. Using these two strains experiments were performed to determine optimal growth conditions before the competition experiments were started. The results showed (data not shown) that with D-glucose as the carbon and electron donor, the growth characteristics of the two species were most optimal for the chemostat experiments. Glucose is also known to be excreted by the roots [15]. $P$. fluorescens denitrifies $\mathrm{NO}_{3}^{-}$entirely to dinitrogen without accumulation of $\mathrm{N}_{2} \mathrm{O}$. B. licheniformis reduces $\mathrm{NO}_{3}^{-}$completely to $\mathrm{NH}_{4}^{+}$, without flocculation of the cells or accumulation of $\mathrm{NO}_{2}^{-}$, when ammonium was available in the medium. The reduction of nitrate beyond the level of nitrite by $B$. licheniformis was dependent on the presence of ammonium [16].

Before starting the chemostat experiments, the maximum specific growth rates $\left(\mu_{\max }\right)$ of $P$. fluorescens and $B$. licheniformis on glucose or acetate as electron donor in the presence or absence of nitrate as electron acceptor were determined in triplicate in 250-ml flasks flushed with dinitrogen. The $\mathrm{pH}$ of the medium at the start of the incubations was 7.5, temperature fluctuated between $22^{\circ} \mathrm{C}$ and $25^{\circ} \mathrm{C}$. During 24-30 h samples were taken to determine the optical density (O.D.), the total number of bacteria and the glucose, acetate and mineral nitrogen concentrations. 
The $\mu_{\max }$ was determined during the exponential growth phase of the strains. The $\mu_{\max }$ values were also determined for both species in a $\mathrm{pH}$-stat $(\mathrm{pH}$ 7.5), temperature $25^{\circ} \mathrm{C}$, with glucose as electron donor and $\mathrm{O}_{2}$ as electron acceptor $(10 \%$ and $80 \%$ air saturation). The $\mu_{\max }$ values of $P$. fluorescens and $B$. licheniformis are given in Table 1 .

\subsection{Medium and growth conditions}

The mineral medium for the chemostat experiments (Biostat M fermenters, B. Braun, Melsungen, Germany; 1.21 culture volume) consisted of (per litre): $0.2 \mathrm{~g} \mathrm{MgSO}_{4} \cdot 7 \mathrm{H}_{2} \mathrm{O}, 0.584 \mathrm{~g} \mathrm{NaCl}, 0.0294 \mathrm{~g}$ $\mathrm{CaCl}_{2} \cdot 2 \mathrm{H}_{2} \mathrm{O}, 1200 \mathrm{mg} \mathrm{K} \mathrm{HPO}_{4}, 920 \mathrm{mg}\left(\mathrm{NH}_{4}^{+}\right)$ $\mathrm{H}_{2} \mathrm{PO}_{4}\left(8.0 \mathrm{mmol} \mathrm{l}^{-1}\right)$ and $10 \mathrm{ml}$ trace-element solution. Trace-element solution contained (per litre): $\mathrm{FeCl}_{2} \cdot 4 \mathrm{H}_{2} \mathrm{O} 2 \mathrm{~g}, \mathrm{Na}_{2}$-EDTA (Titriplex III) $4.3 \mathrm{~g}$, $\mathrm{H}_{3} \mathrm{BO}_{3} 62 \mathrm{mg}, \mathrm{CuCl}_{2} \cdot 2 \mathrm{H}_{2} \mathrm{O} 17 \mathrm{mg}, \mathrm{NiCl}_{2} \cdot 6 \mathrm{H}_{2} \mathrm{O} 24$ $\mathrm{mg}, \mathrm{CoCl}_{2} \cdot 6 \mathrm{H}_{2} \mathrm{O} 24 \mathrm{mg}, \mathrm{MnCl}_{2} \cdot 4 \mathrm{H}_{2} \mathrm{O} \quad 0.1 \mathrm{~g}$, $\mathrm{NaMoO}_{4} \cdot 2 \mathrm{H}_{2} \mathrm{O} 24 \mathrm{mg}$ and $\mathrm{ZnCl}_{2} 68 \mathrm{mg}$. Glucose and nitrate were used in different ratios as electron donor and acceptor, respectively. The stock solutions of D-glucose and the phosphate buffers were autoclaved separately and added to the mineral medium after sterilization. All solutions were kept under oxygen-free nitrogen gas (5.0 Hoek Loos, Schiedam, The Netherlands). P. fluorescens and B. licheniformis were cultured separately in two chemostats until steadystate conditions were obtained [4]. The experiments were performed at $\mathrm{pH} 7.5$ (automatic titration with $0.5 \mathrm{~mol} \mathrm{l}^{-1} \mathrm{HCl}$ and $0.5 \mathrm{~mol} \mathrm{l}^{-1} \mathrm{NaOH}$ ) and at a temperature of $25^{\circ} \mathrm{C}$. The cultures were stirred at 150 r.p.m. at a dilution rate (D) of $0.05 \mathrm{~h}^{-1}$. Purity was checked on solid medium with Tryptic Soy Broth (TSB) and $1 \%$ agar (w/v) enriched with $10 \mathrm{mmol}$ $1^{-1} \mathrm{KNO}_{3}$. Steady states were reached after 5-8 volume changes when the optical density (O.D.), the cell numbers of $P$. fluorescens and $B$. licheniformis, the electron donor and electron acceptor concentrations remained constant.

\subsection{Competition experiments in the chemostat}

The competition experiments started when the two steady-state chemostat cultures of $P$. fluorescens and B. licheniformis were mixed. Therefore $250-\mathrm{ml}$ cultures were anoxically taken from the steady-state cultures and added to the other chemostat. The cell numbers of $P$. fluorescens and B. licheniformis at steady-state conditions determined the mixing ratios of the competition experiments.

The experiments were conducted under (i) electron donor-limited conditions: $2.5 \mathrm{mmol}^{-1}$ D-glucose $+20 \mathrm{mmol} \mathrm{l}^{-1}$ nitrate $(\mathrm{C} / \mathrm{N}=0.75)$, (ii) electron acceptor-limited conditions: $20 \mathrm{mmol} \mathrm{l}^{-1}$ D-glucose $+2.5 \mathrm{mmol}^{-1}$ nitrate $(\mathrm{C} / \mathrm{N}=48.0)$ [4]. The $\mathrm{C} / \mathrm{N}$ ratios were based on the stoichiometric equations, assuming that $P$. fluorescens reduced nitrate entirely to dinitrogen and glucose was oxidised to $\mathrm{CO}_{2}$. For $B$. licheniformis the assumption was made that glucose was totally oxidised to acetate and $\mathrm{CO}_{2}$ and nitrate reduced to ammonium.

To our knowledge nothing is known about the actual oxygen concentrations in the rhizosphere of G. maxima. However, there is a positive correlation between the photosynthetic activity and the amount of oxygen released in the rhizosphere [12]. Therefore, to determine the effect of different periods of photosynthesis (summer $16 \mathrm{~h}$, winter $8 \mathrm{~h}$ ) and hence oxygen concentration, competition between the two species was also tested at two different daily cycles of $10 \%$ air saturation with the same glucose and nitrate concentration: $10 \mathrm{mmol}^{-1} \mathrm{D}$-glucose $+10 \mathrm{mmol} \mathrm{l}^{-1}$ nitrate $(\mathrm{C} / \mathrm{N}=6.0)$ [4]. With a $\mathrm{C} / \mathrm{N}$ ratio of 6.0 , nitrate is limited only for the denitrifying strain. The two anoxic steady-state cultures were flushed with air directly after mixing. One chemostat had a regime of $8 \mathrm{~h} 10 \%$ and $16 \mathrm{~h} 0 \%$ air saturation, whereas the other chemostat had a regime of $16 \mathrm{~h} 10 \%$ and $8 \mathrm{~h}$ $0 \%$ air saturation as measured in the culture. The oxygen concentration was measured with an Ingold oxygen electrode (Ingold, Frankfurt, Germany). Every day samples were taken $4-7 \mathrm{~h}$ after the continuous cultures had shifted to $10 \%$ air saturation, to determine the O.D. $(660 \mathrm{~nm})$, the cell numbers of $P$. fluorescens and B. licheniformis and the concentrations of $\mathrm{NO}_{3}^{-}, \mathrm{NO}_{2}^{-}, \mathrm{NH}_{4}^{+}$, glucose and fatty acids. The competition experiments were continued until stable coexistence was obtained or until one of the strains had washed out.

\subsection{Determination of the numbers of $P$. fluorescens and B. licheniformis}

During the competition experiments the numbers 
of $P$. fluorescens and B. licheniformis were determined daily by Bürker-Türk counting chamber and by plating chemostat samples onto agar $(1 \%, \mathrm{w} / \mathrm{v})$ plates containing TSB medium enriched with $10 \mathrm{mmol}^{-1} \mathrm{KNO}_{3}$. The plates were incubated at $20^{\circ} \mathrm{C}$ and $37^{\circ} \mathrm{C}$. At $37^{\circ} \mathrm{C}$ only B. licheniformis was able to grow. The recovery of $B$. licheniformis cells at this temperature was the same as at $20^{\circ} \mathrm{C}$. The recovery of $P$. fluorescens and B. licheniformis cells determined by plate counts was in the same order of magnitude as the total cell count by Bürker-Türk.

\subsection{Analytical methods}

The O.D. was measured with a Vitatron MCP $(660 \mathrm{~nm})$ (Meyvis Instruments, Bergen op Zoom, The Netherlands). During the competition experiments concentrations of $\mathrm{NO}_{3}^{-}, \mathrm{NO}_{2}^{-}$and $\mathrm{NH}_{4}^{+}$were determined with a Technicon Traacs 800 autoanalyser (Technicon Instruments Corp., Tarrytown, NY, USA). The detection limit for the three compounds was $0.010 \mathrm{mmol} \mathrm{l}^{-1}$. Glucose was determined using a test combination for glucose (Boehringer Mannheim Diagnostica, Mannheim, Germany) based on the GOD-POD method. The detection level was 0.050 mmol $1^{-1}$. The fatty acids were analysed on a high performance liquid chromatograph (HPLC) (Pharmica Biotech., Roosendaal, The Netherlands). Separation proceeded on an OAHY (Merck) organic acids column, at an eluent flow-rate of $0.6 \mathrm{ml}$ $\min ^{-1}\left(10 \mathrm{mmol} \mathrm{1} 1^{-1} \mathrm{H}_{2} \mathrm{SO}_{4}, 10 \mu \mathrm{l}\right.$ sample loop-injected, column temperature $60^{\circ} \mathrm{C}$ ). Sample components were identified with the use of internal standards and quantified by simultaneous UV absorption (206 nm) and refraction index (RI) measurements. The detection level for the fatty acids was 0.010 mmol $1^{-1}$.

\section{Results}

\subsection{Growth characteristics of P. fluorescens and B. licheniformis}

The $\mu_{\max }$ values of $P$. fluorescens and $B$. licheniformis are given in Table 1 . The $\mathrm{pH}$ of the batch cultures decreased only slightly during the incubation, no more than $0.1-0.2 \mathrm{pH}$ units (data not shown). The results in Table 1 show that under all conditions tested, the $\mu_{\max }$ of $P$. fluorescens was higher than that of $B$. licheniformis. There was no difference in $\mu_{\max }$ between $10 \%$ and $80 \%$ air saturation, indicating excess electron acceptor even at 10\% air saturation. $P$. fluorescens was able to utilise acetate with nitrate as electron donor, whereas $B$. licheniformis was able to ferment glucose under anoxic conditions.

The steady-state concentrations of mineral nitrogen, glucose and volatile fatty acids in glucose- or nitrate-limited chemostat mono-cultures of $P$. fluorescens and $B$. licheniformis under continuous anoxic conditions are given in Table 2.

Under glucose-limited conditions $(\mathrm{C} / \mathrm{N}=0.75) P$. fluorescens reduced $8.3 \mathrm{mmol}^{-1}$ nitrate, without the accumulation of nitrite, and a small amount of acetate was produced. Under nitrate-limited conditions $(\mathrm{C} / \mathrm{N}=6.0), 6.50 \mathrm{mmol} \mathrm{l}^{-1}$ glucose remained in the chemostat and there was no nitrate, nitrite or acetate detectable (Table 2). These concentrations agree well with the stoichiometric equation regarding the reduction of nitrate with glucose as carbon source, leaving the endogenous metabolism of $P$. $f l u$ orescens out of consideration. The glucose concentration at steady state also under nitrate-limited conditions but with excess glucose $(\mathrm{C} / \mathrm{N}=48.0)$ was much lower than expected regarding the above mentioned equation (Table 2). This indicates that glucose

Table 1

Maximum growth rates $\left(\mu_{\max }\right)$ of Pseudomonas fluorescens and Bacillus licheniformis under different incubation conditions

\begin{tabular}{lllll}
\hline & $\mu_{\max }\left(\mathrm{h}^{-1}\right)$ & $\mu_{\max }\left(\mathrm{h}^{-1}\right)$ & $\mu_{\max }\left(\mathrm{h}^{-1}\right)$ & $\mu_{\max }\left(\mathrm{h}^{-1}\right)$ \\
Electron donor & $\mathrm{D}-\mathrm{Glucose}$ & $\mathrm{D}-\mathrm{Glucose}$ & $\mathrm{D}-\mathrm{Glucose}$ & Acetate \\
Electron acceptor & $\mathrm{O}_{2}$ & $\mathrm{NO}_{3}^{-}$ & None & $\mathrm{NO}_{3}^{-}$ \\
\hline $\begin{array}{l}\text { P. fluorescens } \\
\text { B. licheniformis }\end{array}$ & $0.36 \pm 0.14$ & $0.15 \pm 0.01$ & no growth & $0.08 \pm 0.01$ \\
\hline
\end{tabular}

With nitrate or none electron acceptor the $\mu_{\max }$ values were determined in batch cultures: initial $\mathrm{pH} 7.5$, temperature $22-25^{\circ} \mathrm{C}$. With oxygen as electron acceptor, $10 \%$ and $80 \%$ air saturation, the $\mu_{\max }$ values were determined in a pH-stat: $\mathrm{pH} 7.5$, temperature $25^{\circ} \mathrm{C}$. 
was not completely oxidised to $\mathrm{CO}_{2}$ and another oxidised organic carbon product must be present. This was indeed the case: with excess glucose $P$. fluorescens produced an unidentified organic carbon product. This product was detectable on the HPLC with RI measurement, whereas with UV absorption the product was not detectable, indicating that the unknown product is not an organic acid. Under these conditions no pyruvate, succinate or formate was detected.

The results showed that $B$. licheniformis reduced more than half of the available $\mathrm{NO}_{3}^{-}$only to $\mathrm{NO}_{2}^{-}$ without the formation of $\mathrm{NH}_{4}^{+}$, under glucose-limited conditions $(\mathrm{C} / \mathrm{N}=0.75)$ (Table 2). Under this condition the nitrogen balance was almost $100 \%$. With 10 mmol $1^{-1}$ glucose and nitrate $(\mathrm{C} / \mathrm{N}=6.0)$, the $\mathrm{NO}_{2}^{-}$ concentration was low and a slight increase in $\mathrm{NH}_{4}^{+}$ was detectable. Under nitrate-limited conditions $(\mathrm{Cl}$ $\mathrm{N}=48.0$ ) the $\mathrm{NH}_{4}^{+}$concentration decreased to 4.65 mmol $1^{-1}$. Under this condition the culture of $B$. licheniformis contained different organic carbon products: lactate, formate and acetate. The nitrogen balances with $\mathrm{C} / \mathrm{N}$ ratio of 6.0 and 48.0 were $61 \%$ and $44 \%$, respectively (Table 2 ).

The unknown organic carbon product, present in the $P$. fluorescens culture under nitrate-limited conditions $(\mathrm{C} / \mathrm{N}=48.0)$, as well as succinate and pyruvate, were not detectable in the cultures of $B$. licheniformis under any of the conditions applied. Ethanol was present at low concentrations in the P. fluorescens and in the B. licheniformis cultures, but could not be measured accurately.

\subsection{Competition under continuous anoxic glucose-limited conditions}

Competition between $P$. fluorescens and B. licheniformis under glucose-limited conditions $(\mathrm{C} / \mathrm{N}=0.75)$, is presented in Fig. 1. Competition started when 250 $\mathrm{ml}$ of $B$. licheniformis culture $\left(2.78 \times 10^{8} \mathrm{ml}^{-1}\right)$ was added to the steady-state culture of $P$. fluorescens, resulting in a mixing ratio between $P$. fluorescens and $B$. licheniformis of 5.41. The cell percentage of $P$. fluorescens decreased sharply after mixing, concomitantly with the accumulation of nitrite in the culture (Fig. 1A,C). After 4 volume changes of the competition, the cell percentage of $P$. fluorescens increased steadily and reached $97-98 \%$ of the total cell numbers determined on the TSB plates at the end of the experiment. At the same time, nitrite disappeared again from the culture. There were no organic carbon products detectable; only at the end of the competition experiment $0.75 \mathrm{mmol}^{-1}$ acetate was measured.

In the chemostat where $250 \mathrm{ml} P$. fluorescens culture $\left(5.34 \times 10^{8} \mathrm{ml}^{-1}\right)$ was added to the steady-state culture of $B$. licheniformis, the competition started at a ratio between $P$. fluorescens and $B$. licheniformis of 0.78 (Fig. 1D-F). When P. fluorescens was added the $\mathrm{NO}_{2}^{-}$concentration rapidly decreased to zero (Fig. 1D). $\mathrm{NO}_{2}^{-}$was probably reduced by $P$. fluorescens with acetate as the carbon source. Acetate decreased from $2.19 \mathrm{mmol}^{-1}$ to zero in less than 1 volume change and the cell numbers of $P$. fluorescens rapidly increased. When $\mathrm{NO}_{2}^{-}$could not be detected any

Table 2

Steady-state concentrations of mineral nitrogen, glucose and volatile fatty acids in glucose-or-nitrate limited cultures of Pseudomonas fluorescens and Bacillus licheniformis under continuous anoxic conditions (the concentrations are given in $\mathrm{mmol} 1^{-1}$ )

\begin{tabular}{|c|c|c|c|c|c|c|c|c|c|c|}
\hline & \multicolumn{3}{|c|}{ Incubation conditions } & \multirow[t]{2}{*}{$\mathrm{NO}_{3}^{-}$} & \multirow[t]{2}{*}{$\mathrm{NO}_{2}^{-}$} & \multirow[t]{2}{*}{$\mathrm{NH}_{4}^{+}$} & \multirow[t]{2}{*}{ D-Glucose } & \multirow[t]{2}{*}{ Acetate } & \multirow[t]{2}{*}{ Lactate } & \multirow[t]{2}{*}{ Formate } \\
\hline & Glucose & Nitrate & $\mathrm{C} / \mathrm{N}$ ratio & & & & & & & \\
\hline \multirow[t]{3}{*}{ Pseudomonas fluorescens } & 2.5 & 20 & 0.75 & 11.68 & 0.0 & 6.26 & $<0.05$ & 0.35 & & \\
\hline & 10 & 10 & 6.0 & $<0.01$ & 0.0 & 5.10 & 6.50 & 0.0 & & \\
\hline & 20 & 2.5 & 48.0 & $<0.01$ & $<0.01$ & 6.50 & 7.86 & 0.0 & & \\
\hline \multirow[t]{3}{*}{ Bacillus licheniformis } & 2.5 & 20 & 0.75 & 9.52 & 10.64 & 7.04 & $<0.05$ & 2.19 & 0.00 & 0.00 \\
\hline & 10 & 10 & 6.0 & 0.02 & 1.06 & 9.90 & $<0.05$ & 6.77 & 0.00 & 0.00 \\
\hline & 20 & 2.5 & 48.0 & $<0.01$ & $<0.01$ & 4.65 & $<0.05$ & 7.15 & 5.28 & 5.58 \\
\hline
\end{tabular}

The chemostat conditions were: Dilution rate $0.05 \mathrm{~h}^{-1}$, temperature $25^{\circ} \mathrm{C}$ and $\mathrm{pH} 7.5$. The initial $\mathrm{NH}_{4}^{+}$concentration in the medium was $8.0 \mathrm{mmol} \mathrm{l}^{-1}$. 


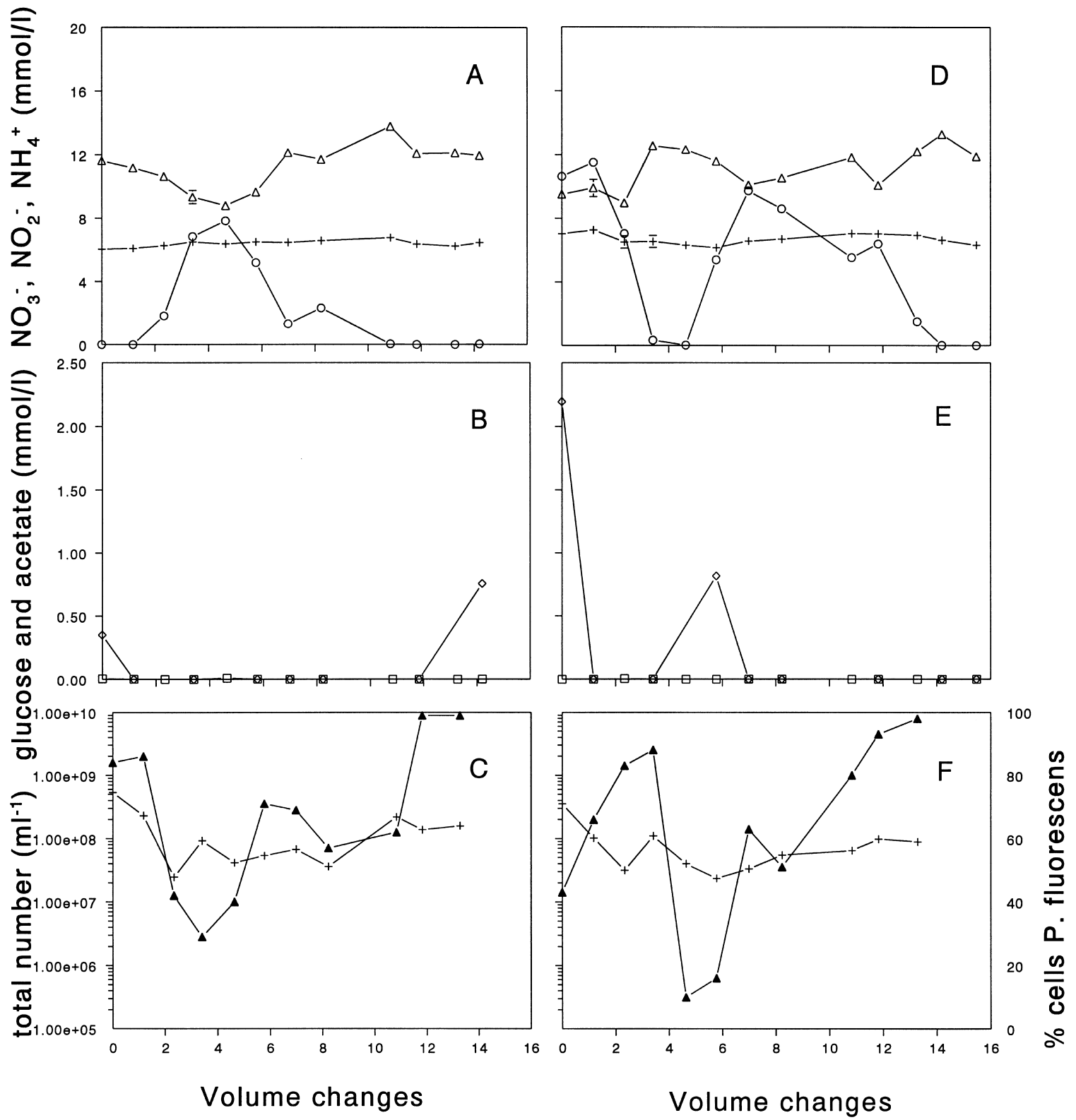

Fig. 1. Competition for glucose between Pseudomonas fluorescens and Bacillus licheniformis in a glucose-limited chemostat under continuous anoxic conditions. Dilution rate (D) was $0.05 \mathrm{~h}^{-1}$. The medium contained $2.5 \mathrm{mmol} \mathrm{1^{-1 }}$ D-glucose and $20 \mathrm{mmol} \mathrm{l}^{-1}$ nitrate $(\mathrm{C} /$ $\mathrm{N}=0.75$ ). At the start of the experiment steady-state mono-cultures of both strains were mixed. The data in A-C are the result of adding $250 \mathrm{ml}$ of the $B$. licheniformis culture to the culture of $P$. fluorescens. The competition started with a ratio between $P$. fluorescens and $B$. licheniformis of 5.41. The data in D-F resulted from $250 \mathrm{ml}$ of the $P$. fluorescens culture being added to the culture of $B$. licheniformis. Initial ratio between $P$. fluorescens and $B$. licheniformis cells at the competition was 0.78 . Panels A and D present concentrations of nitrate (open triangles), nitrite (open circles), ammonium (crosses); panels B and E present concentrations of glucose (open squares) and acetate (open diamonds); and panels $\mathrm{C}$ and $\mathrm{F}$ present total numbers of Pseudomonas fluorescens plus Bacillus licheniformis determined by plate counts (crosses) and the percentage cell counts of Pseudomonas fluorescens compared to the total plate counts (closed triangles). 


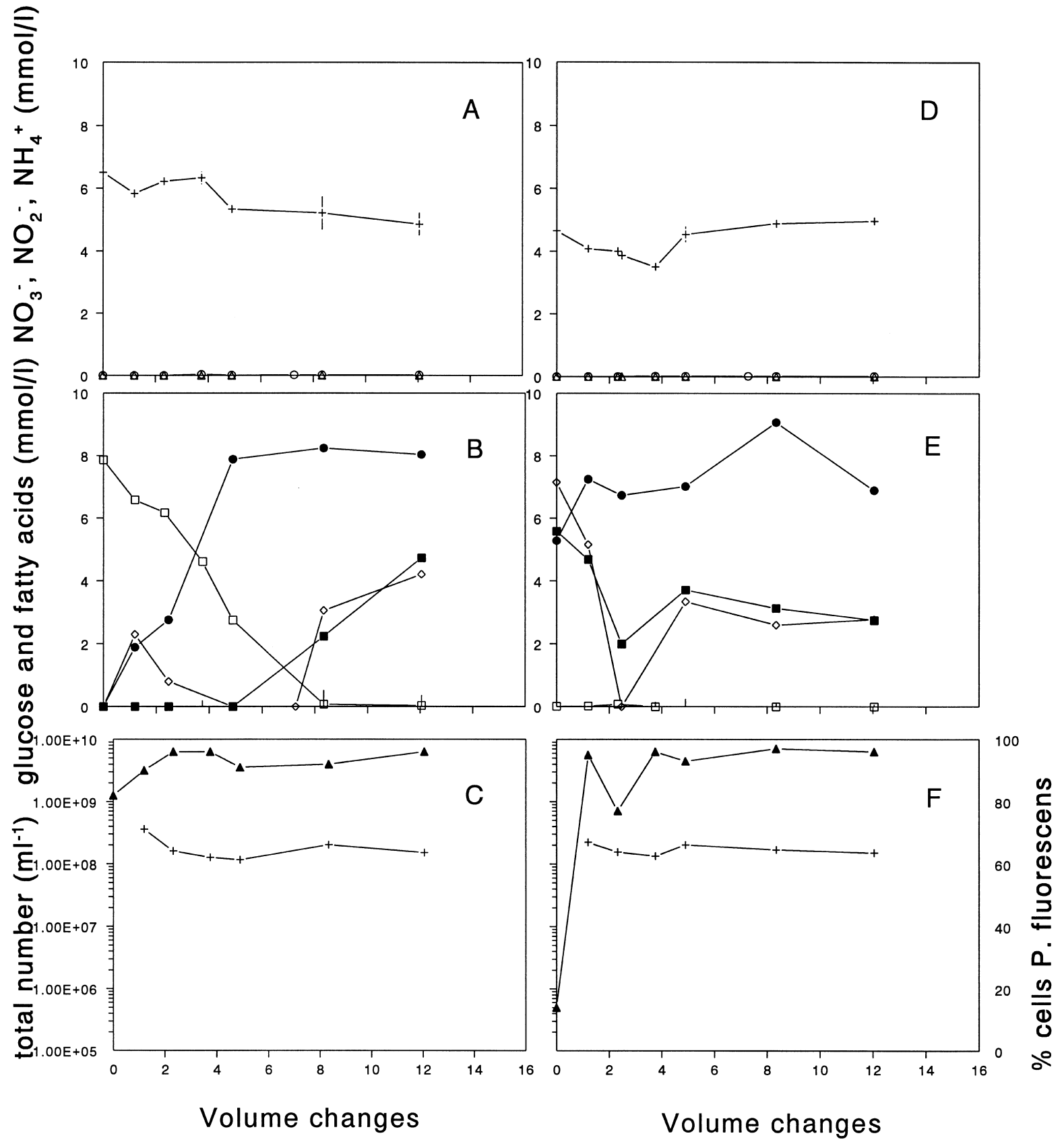

Fig. 2. Competition for nitrate between Pseudomonas fluorescens and Bacillus licheniformis in a nitrate-limited chemostat under continuous anoxic conditions. Dilution rate (D) was $0.05 \mathrm{~h}^{-1}$. The medium contained $20 \mathrm{mmol} \mathrm{l}^{-1} \mathrm{D}$-glucose and $2.5 \mathrm{mmol} \mathrm{l}^{-1} \mathrm{nitrate}(\mathrm{C} / \mathrm{N}=48.0)$. The data in $\mathrm{A}-\mathrm{C}$ are the result of adding $250 \mathrm{ml}$ of the B. licheniformis culture to the culture of $P$. fluorescens. The competition started with a ratio between $P$. fluorescens and B. licheniformis of 4.67. The data in D-F resulted from $250 \mathrm{ml}$ of the $P$. fluorescens culture being added to the culture of B. licheniformis. Initial ratio between P. fluorescens and B. licheniformis cells at the competition was 0.16 . Panels $\mathrm{A}$ and D present concentrations of nitrate (open triangles), nitrite (open circles) and ammonium (crosses); panels B and E present glucose (open squares), acetate (open diamonds), formate (closed squares) and lactate (closed circles); and panels $\mathrm{C}$ and $\mathrm{E}$ present total numbers of Pseudomonas fluorescens plus Bacillus licheniformis determined by plate counts (crosses) and the percentage cell counts of Pseudomonas fluorescens compared to the total plate counts (closed triangles). 
longer, the cell percentage of $P$. fluorescens decreased while the acetate and $\mathrm{NO}_{2}^{-}$concentrations increased again. After 6 volume changes, the number of $P$. fluorescens started gradually to increase, acetate decreased again rapidly and the $\mathrm{NO}_{2}^{-}$concentration slowly decreased until it was not detectable after 14 volume changes. In addition under this mixing regime $P$. fluorescens out-competed B. licheniformis, comprising $98-99 \%$ of the total number of colonies determined on the plates at the end of the experiment.

\subsection{Competition under continuous anoxic nitrate-limited conditions}

The competition experiment with glucose (20 mmol $\left.1^{-1}\right)$ and nitrate $\left(2.5 \mathrm{mmol} \mathrm{l}^{-1}\right)$, with nitrate being the limited substrate for both strains $(\mathrm{C} /$ $\mathrm{N}=48.0$ ), is presented in Fig. 2.

Competition started when B. licheniformis was added $\left(7.46 \times 10^{8} \mathrm{ml}^{-1}\right)$ to the steady-state culture of $P$. fluorescens, resulting in a mixing ratio between P. fluorescens and B. licheniformis of 4.67 (Fig. 2AC). During competition the glucose concentration decreased to zero over a time period of 8.2 volume changes, whereas the concentration of lactate gradually increased to $8 \mathrm{mmol}^{-1}$. The formate and acetate concentrations were $4.5 \mathrm{mmol}^{-1}$ at the end of the experiment. There were no strong fluctuations in cell numbers of $P$. fluorescens or B. licheniformis. The cell percentage of $P$. fluorescens reached a constant level of $96 \%$ of the total plate counts. B. licheniformis remained constant at around $4 \%$. The competition resulted in coexistence, although the number of the fermentative $B$. licheniformis strain was rather low, i.e. $1 \times 10^{7}$ cells $\mathrm{ml}^{-1}$. Apparently, the remaining glucose was fermented by B. licheniformis to lactate, formate and acetate. The unknown organic carbon product present during steady-state in the pure culture of $P$. fluorescens was not detectable any more after 2 volume changes; this product was apparently fermented by $B$. licheniformis (data not shown).

In the other competition experiment, a $250-\mathrm{ml}$ culture of $P$. fluorescens $\left(5.74 \times 10^{8} \mathrm{ml}^{-1}\right)$ was added to the $B$. licheniformis culture, resulting in a initial competition ratio between $P$. fluorescens and B. licheniformis of 0.16 (Fig. 2D-F). The concentrations of acetate and formate decreased and the number of $P$. fluorescens rapidly increased during the first 2.5 volume changes. The lactate concentrations slightly fluctuated but overall remained the same. The formate and acetate concentration stabilised around 2.7 mmol $1^{-1}$. Also, in this experiment the percentage of the denitrifying $P$. fluorescens reached a constant level of $96 \%$. B. licheniformis remained in the chemostat by fermenting the remaining glucose.

\subsection{Competition under fluctuating oxic-anoxic conditions}

The competition experiment with glucose (10 mmol $\left.\mathrm{l}^{-1}\right)$ and nitrate $\left(10 \mathrm{mmol} \mathrm{l}^{-1}\right)(\mathrm{C} / \mathrm{N}=6.0)$ under fluctuating oxic conditions is presented in Fig. 3.

$B$. licheniformis was added to the $P$. fluorescens culture, resulting in a cell ratio of $P$. fluorescens/ $B$. licheniformis of 2.24 with an oxygen regime of $8 \mathrm{~h}$ $10 \%$ and $16 \mathrm{~h} 0 \%$ air saturation (Fig. 3A-C). In the chemostat where $P$. fluorescens was added to the $B$. licheniformis culture the initial cell ratio of $P$. fluorescens/B. licheniformis was 0.20 , with an oxygen regime of $16 \mathrm{~h} \mathrm{10 \%}$ air saturation and $8 \mathrm{~h} 0 \%$ (Fig. $3 \mathrm{D}-\mathrm{F})$. The samples were all taken in a period $4-7 \mathrm{~h}$ after the chemostats shifted to $10 \%$ air saturation, since the time of sampling during these competition experiments was critical. The competition with $8 \mathrm{~h}$ $10 \%$ air saturation resulted in coexistence, with $P$. fluorescens comprising $96 \%$ of the total population. Under this competition condition, nitrate was limited for $P$. fluorescens and despite the regime of $8 \mathrm{~h} \mathrm{10 \%}$ air saturation, a part of the glucose must have been available for $B$. licheniformis.

In the experiment with $16 \mathrm{~h} 10 \%$ air saturation (Fig. 3D-F), P. fluorescens oxidised all the available acetate prior to 2 volume changes. The number of $P$. fluorescens increased and no glucose remained for $B$. licheniformis. This competition experiment resulted in a wash-out of $B$. licheniformis.

\section{Discussion}

The fermentation products of $B$. licheniformis with a dilution rate of $0.05 \mathrm{~h}^{-1}$ were acetate, lactate, formate, ethanol and $\mathrm{CO}_{2}$. The fermentation balance of 


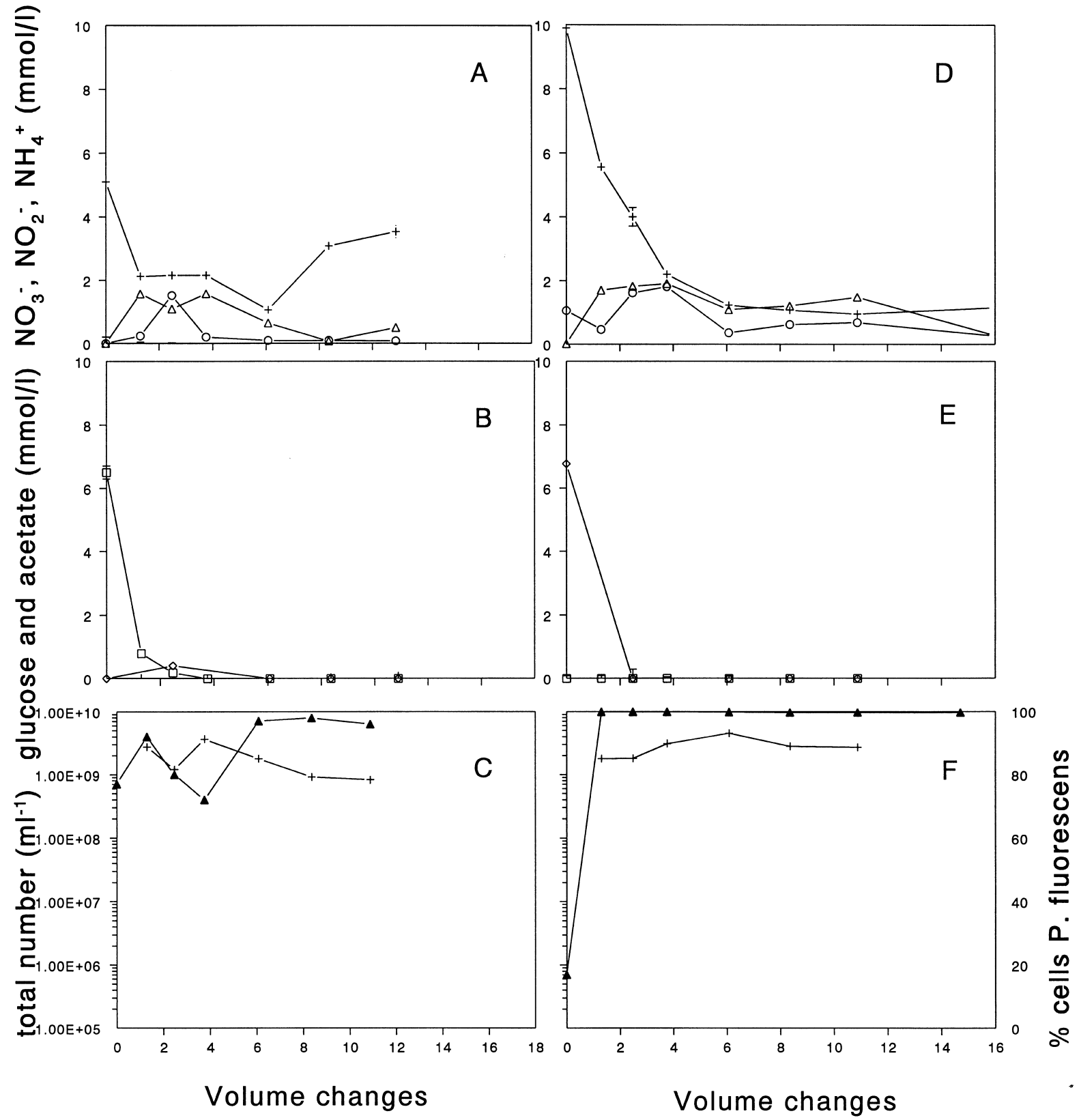

Fig. 3. Competition between Pseudomonas fluorescens and Bacillus licheniformis in a chemostat under fluctuating oxic-anoxic conditions. Dilution rate (D) was $0.05 \mathrm{~h}^{-1}$. The medium contained $10 \mathrm{mmol} \mathrm{l}^{-1} \mathrm{D}$-glucose and $10 \mathrm{mmol} \mathrm{l}^{-1}$ nitrate $(\mathrm{C} / \mathrm{N}=6.0)$. The data in $\mathrm{A}-\mathrm{C}$ are the result of adding $250 \mathrm{ml}$ of the $B$. licheniformis culture to the culture of $P$. fluorescens. The competition started with a ratio between $P$. fluorescens and B. licheniformis of 2.24 . The data in D-F resulted from $250 \mathrm{ml}$ of the $P$. fluorescens culture being added to the culture of B. licheniformis. Initial ratio between $P$. fluorescens and B. licheniformis cells at the competition was 0.13 . The competition experiments were performed with an oxygen regime of $8 \mathrm{~h} 10 \%$ and $16 \mathrm{~h} 0 \%$ air saturation $(\mathrm{A}-\mathrm{C})$ and with a regime of $16 \mathrm{~h} 10 \%$ and $8 \mathrm{~h} 0 \%$ air saturation (D-F). Panels A and D present concentrations of nitrate (open triangles), nitrite (open circles), ammonium (crosses); panels B and E present concentrations of glucose (open squares) and acetate (open diamonds); and panels $\mathrm{C}$ and $\mathrm{F}$ present total numbers of Pseudomonas fluorescens plus Bacillus licheniformis determined by plate counts (crosses) and the percentage cell counts of Pseudomonas fluorescens compared to the total plate counts (closed triangles). 
B. licheniformis with glucose as carbon source is dependent on the growth rate [17].

The competition experiment under glucose-limited conditions $(\mathrm{C} / \mathrm{N}=0.75)$ resulted in a wash-out of $B$. licheniformis (Fig. 1C,F). There was no $\mathrm{NH}_{4}^{+}$production, and at least at the end of the competition no $\mathrm{NO}_{2}^{-}$accumulation. The high nitrite concentration at the beginning of the competition experiment with a ratio of $P$. fluorescens/B. licheniformis of 0.78 (Fig. 1D) had been caused by $B$. licheniformis, reducing nitrate only to nitrite without accumulation of ammonium. The addition of $P$. fluorescens led to a linear decrease of the formed nitrite from the beginning of the competition experiment.

During these competition experiments there was in both chemostats an unexpected temporary $\mathrm{NO}_{2}^{-}$accumulation (Fig. 1A,D) and, at the same time, a sharp decrease in cell numbers of $P$. fluorescens (Fig. 1C,F). The different rates of nitrate and nitrite reduction by $P$. fluorescens or the competition between nitrate and nitrite reduction pathways for electrons $[18,19]$ may account for a part of the $\mathrm{NO}_{2}^{-}$ accumulation. However, the explanation for the $\mathrm{NO}_{2}^{-}$accumulation remains incomplete.

The competition experiments under nitrate-limited conditions $(\mathrm{C} / \mathrm{N}=48.0)$ (Fig. 2) resulted in coexistence of both species, although the cell numbers of $B$. licheniformis were very low: $4 \%$ of the total numbers of cells determined by plate counts. B. licheniformis was apparently dependent on the fermentation of glucose. The reason for the low number of $B$. licheniformis in these competition experiments, despite the high concentration of glucose available, is not known.

The following conclusions can be drawn regarding the competition experiments that were performed under continuous anoxic conditions with glucose or nitrate limitation. Under glucose-limited conditions $(\mathrm{C} / \mathrm{N}=0.75)$ the competition resulted in the washout of $B$. licheniformis, indicating that the affinity for glucose is higher for $P$. fluorescens than for $B$. licheniformis. Under nitrate-limited conditions $(\mathrm{C} /$ $\mathrm{N}=48.0) P$. fluorescens also wins the competition for nitrate, but $B$. licheniformis is able to maintain itself in the chemostat due to the possibility to ferment the remaining glucose. Under the tested conditions $P$. fluorescens has also a higher affinity for nitrate than $B$. licheniformis. These conclusions are in agreement with other experiments. Enrichments in the chemostat under anoxic conditions with a dilution rate of $0.05 \mathrm{~h}^{-1}$ with glycerol as carbon source, in the presence of limiting amounts of nitrate, resulted in coexistence of fermentative enterobacteria and bacteria with an oxidative metabolism [20]. Fermentative bacteria were only able to maintain high numbers when the supply of oxygen or nitrate was limited. The conclusion was drawn that oxidative bacteria such as pseudomonads and acinetobacteria were better competitors for limiting amounts of electron acceptors.

The results of the competition under fluctuating anoxic conditions, $8 \mathrm{~h} 10 \%$ and $16 \mathrm{~h} 0 \%$ air saturation (Fig. 3A-C) to $16 \mathrm{~h} 10 \%$ and $8 \mathrm{~h} 0 \%$ air saturation (Fig. 3D-F), showed that the numbers of $P$. fluorescens cells contributed for $96 \%$ and $100 \%$ of the total number of bacteria determined by plate counts, respectively. This indicates that with longer oxic periods, $P$. fluorescens utilised all the available glucose with nitrate or oxygen as electron acceptor. With shorter oxic periods $B$. licheniformis was able to maintain itself, probably due to fermentation of the remaining glucose during anoxic periods as the nitrate concentration was limiting under these conditions for P. fluorescens.

The results showed that $P$. fluorescens was able to utilise nitrate and oxygen simultaneously, since the samples taken during the periods of $10 \%$ air saturation contained low to not detectable nitrate concentrations. However, anoxic niches could have been formed in the chemostat during the $10 \%$ air saturation periods, since stirring activity might have been too low [20].

Other studies have shown that the synthesis and activity of the reductases involved by the reduction of nitrate may occur under different oxygen concentrations. The mechanism of oxygen inhibition or repression of denitrification appears to differ for each reductase and denitrifying species [21-25]. There are two types of nitrite reductase found in denitrifiers, an oxygen tolerant cytochrome $c d_{1}$ nitrite reductase and an oxygen sensitive $\mathrm{Cu}$-containing nitrite reductase [26]. It is the general opinion that the $\mathrm{Cu}$-type nitrite reductase cannot be active in intact cells in the presence of oxygen [21]. It is likely that $P$. Aluorescens contains a cytochrome $c d_{1}$ nitrite reductase [27]. 
Based on our results we can attempt to describe the dissimilatory processes related to nitrate in the rhizosphere of aerenchymatous plants and to discuss this in relation to the hypothesis formulated. The results of this study showed that $P$. fluorescens had a higher affinity for both glucose and nitrate than $B$. licheniformis. B. licheniformis was only able to maintain itself in the chemostat under glucose excess by fermenting the remaining glucose. Assuming that carbon is in excess and the electron-acceptor concentrations are limiting, as is often the case in the rhizosphere of waterlogged plants, fermentative bacteria are able to grow and thereby increasing their biomass. B. licheniformis produces nitrate reductase in the presence and absence of nitrate [28]. By oxygen release in the rhizosphere of aerenchymatous plants, nitrification might take place [9] and the nitrate produced might be reduced to either ammonium or dinitrogen. Initially, the nitrate reduction pathway to be taken depends largely on the biomass of the two dissimilatory nitrate-reducing subcommunities present. After a relative long period of anoxic conditions, most available nitrate will be reduced to $\mathrm{NH}_{4}^{+}$due to the larger active biomass of the fermentative bacteria $[11,14]$. When the period of nitrate availability increases, the oxidative denitrifying strains will dominate, since the denitrifying strains apparently have a higher affinity for nitrate and a higher growth rate than fermentative bacteria. The results of our experiments support the above mentioned processes, however, under glucose-limited conditions $(\mathrm{C} / \mathrm{N}=0.75)$ (Table 2 and Fig. 1D) $B$. licheniformis reduced nitrate only to nitrite instead of ammonium. Under these circumstances there was no reason to use nitrite as electron sink as the reduction of nitrate was the energy providing step $[2,18]$.

The rhizosphere of aerenchymatous plants is a very heterogeneous environment due to the release of oxygen and different organic carbon compounds. Around the roots there may be a zone shifting between aerobic processes during the day and anaerobic processes during the night [5]. In nature the competition between denitrifying and nitrate-ammonifying bacteria for nitrate and organic carbon can also be controlled by other factors than affinities and growth rates. Therefore, in future more research is necessary to examine the competition between deni- trifying and fermentative nitrate-reducing bacteria in the rhizosphere of aerenchymatous plants.

\section{Acknowledgments}

We want to thank the Deutsche Sammlung von Mikro-organismen und Zellkulturen $\mathrm{GmbH}$ at Braunschweig in Germany for the identification of the denitrifying strain Pseudomonas fluorescens (Biovar III or IV) and the fermentative nitrate-reducing strain Bacillus licheniformis. Special thanks to Wim Roelofsen of the Department of Microbiology, University of Wageningen for the determinations of the volatile fatty acids. Finally we want to acknowledge Justin Clapp and Jan Woldendorp for critical reading of the manuscript.

\section{References}

[1] Knowles, R. (1982) Denitrification. Microbiol. Rev. 46, 43-70.

[2] Tiedje, J.M. (1988) Ecology of denitrification and dissimilatory nitrate reduction to ammonium. In: Biology of Anaerobic Microorganisms (Zehnder, A.J.B., Ed.), pp. 179-224. Wilder, New York, NY.

[3] Tiedje, J.M., Sexstone, A.J., Myrold, D.D. and Robinson, J.A. (1982) Denitrification: ecological niches, competition and survival. Antonie van Leeuwenhoek 48, 569-583.

[4] Rehr, B. and Klemme, J.H. (1989) Competition for nitrate between denitrifying Pseudomonas stutzeri and nitrate-ammonifying enterobacteria. FEMS Microbiol. Ecol. 62, 51-58.

[5] Sand-Jensen, K., Prahl, C. and Stokholm, H. (1982) Oxygen release from roots of submerged aquatic macrophytes. Oikos 38, 349-354.

[6] Armstrong, W., Armstrong, J. and Beckett, P.M. (1990) Measurement and modelling of oxygen release from roots of Phragmites australis. In: Use of Constructed Wetlands in Water Pollution Control (Cooper, P.F. and Findlater, B.C., Eds.). Adv. Water Poll. Control 11, 41-52.

[7] Reddy, K.R., Patrick, W.H. Jr. and Lindau, C.W. (1989) Nitrification-denitrification at the plant root-sediment interface in wetlands. Limnol. Oceanogr. 34, 1004-1013.

[8] Both, G.J. (1990) Ph.D Thesis. University of Groningen, Groningen.

[9] Bodelier, P.L.E., Libochant, J.A., Blom, C.W.P.M. and Laanbroek, H.J. (1996) Dynamics of nitrification and denitrification in root-oxygenated sediments and adaptation of ammonia-oxidizing bacteria to low oxygen or anoxic habitats. Appl. Environ. Microbiol. 62, 1400-1407.

[10] Bodelier, P.L.E., Wijlhuizen, A.G., Blom, C.W.P.M. and Laanbroek, H.J. (1997) Effects of photoperiod on growth of and denitrification by Pseudomonas chlororaphis in the root 
zone of Glyceria maxima studied in a gnotobiotic microcosm. Plant Soil 190, 91-103.

[11] Nijburg, J.W., Coolen, M.J.L., Gerards, S., Klein Gunnewiek, P.J.A. and Laanbroek, H.J. (1997) Effects of nitrate availability and the presence of Glyceria maxima on the composition and activity of the dissimilatory nitrate-reducing bacterial community. Appl. Environ. Microbiol. 63, 931-937.

[12] Scaglia, J., Lensi, R. and Chalamet, A. (1985) Relationship between photosynthesis and denitrification in planted soil. Plant Soil 84, 37-43.

[13] Prade, K. and Trolldenier, G. (1990) Denitrification in the rhizosphere of plants with inherently different aerenchyma formation: Wheat (Triticum aesticum) and Rice (Oryza sativa). Biol. Fertil. Soils 9, 215-219.

[14] Nijburg, J.W. and Laanbroek, H.J. (1997) The influence of Glyceria maxima and nitrate input on the composition and nitrate metabolism of the dissimilatory nitrate-reducing community. FEMS Microbiol. Ecol. 22, 57-63.

[15] Curl, A. and Truelove B. (1986) In: The Rhizosphere, pp. 5591. Springer-Verlag, Berlin.

[16] Konohana, T., Murakami, S., Nanmori, T., Aoki, K. and Shinke, R. (1993) Increase in nitrate reductase activity with ammonium chloride in Bacillus licheniformis by shaking culture. Biosci. Biotech. Biochem. 57, 2170-2171.

[17] Bulthuis, B.A. (1990) Ph.D Thesis. Vrije University of Amsterdam, Amsterdam.

[18] Woldendorp, J.W. (1963) Ph.D Thesis. University of Wageningen, Wageningen.

[19] Van Rijn, J., Tal, Y. and Barak, Y. (1996) Influence of volatile fatty acids on nitrite accumulation by a Pseudomonas stutzeri strain isolated from a denitrifying fluidized bed reactor. Appl. Environ. Microbiol. 62, 2615-2620.
[20] Brunel, B., Janse, J.D., Laanbroek, H.J. and Woldendorp, J.W. (1992) Effect of transient oxic conditions on the composition of the nitrate-reducing community from the rhizosphere of Typha angustifolia. Microbiol. Ecol. 24, 51-61.

[21] Otte, S., Grobben, N.G., Robertson, L.A., Jetten, M.S.M. and Kuenen, J.G. (1996) Nitrous oxide production by Alcaligenes faecalis under transient and dynamic aerobic and anaerobic conditions. Appl. Environ. Microbiol. 62, 2421-2426.

[22] Bonin, P., Gilewicz, M. and Bertrand, J.C. (1989) Effects of oxygen on each step of denitrification on Pseudomonas nautica. Can. J. Microbiol. 35, 1061-1064.

[23] McKenney, D.J., Drury, C.F., Findlay, W.I., Mutus, B., McDonnell, T. and Gajda, C. (1994) Kinetics of denitrification by Pseudomonas fluorescens: oxygen effects. Soil Biol. Biochem. 26, 901-908.

[24] Patureau, D., Bernet, N. and Moletta, R. (1996) Effect of oxygen on denitrification in continuous culture with Commamonas sp. SGLY 2. J. Industr. Microbiol. 16, 124-128.

[25] Kester, R.A., de Boer, W. and Laanbroek H.J. (1997) Production of $\mathrm{NO}$ and $\mathrm{N}_{2} \mathrm{O}$ by pure cultures of nitrifying and denitrifying bacteria during changes in aeration. Appl. Environ. Microbiol. 63, 3872-3877.

[26] Ferguson, S.J. (1994) Denitrification and its control. Antonie van Leeuwenhoek 66, 89-110.

[27] Zumft, W.G. (1992) The denitrifying prokaryotes. In: The Prokaryotes (Balows, A., Trüper, H.G., Dworkin, M., Harder, W. and Schleifer, K.H., Eds.), 2nd Edn., pp. 554-582. Springer Verlag, Berlin.

[28] Schulp, J.A. and Stouthamer, A.H. (1970) The influence of oxygen, glucose and nitrate upon the formation of nitrate reductase and the respiratory system in Bacillus licheniformis. J. Gen. Microbiol. 64, 195-203. 